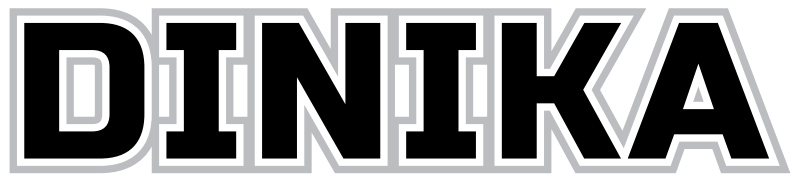

Academic Journal of Islamic Studies

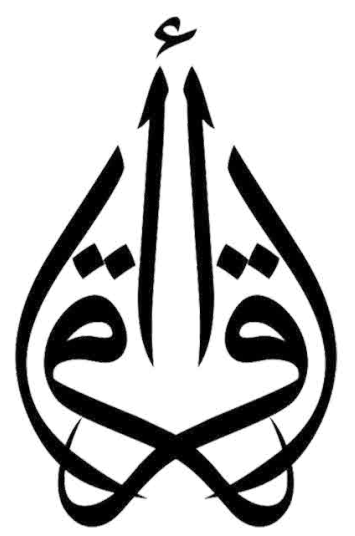


Volume 4, Number 3, September - December 2019 ISSN: 2503-42I 9 (p); 2503-4227 (e)

\section{DINIKA}

Academic Journal of Islamic Studies

\section{Table of Contents}

\section{Main Articles:}

Muslimab Beauty Veiling, Piety and Commodity in the New Indonesian

Public Sphere

Yuyun Sunesti

Competing Identity and Culture: The Formation of Forum Lingkar Pena and Komunitas Matapena in Indonesia

Nor Ismah

Ria Ricis and New Platform of Islamic Popular Culture

Wahyudi Akmaliah

\section{Articles:}

Perseteruan Memori Kolektif Kontestasi Islam dan Politik di

Tasikmalaya Pasca-Orde Baru

Amin Mudzakkir

Qital: Reinterpretasi Pendekatan Humanis

Ana Rahmawati, Azzah Nor Laila

The Characteristics of Philosophical Knowledge of The Qur'an and Prophetic Revelation According to Muni Laswad in His Book Islâm al-Falâsifa

Muhammad Makmun, Dessy Yanti Srie Budiningsih 


\title{
Qital: Reinterpretasi Pendekatan Humanis
}

\author{
Ana Rahmawati \\ UNISNU Jepara \\ email:bundacacajpr@gmail.com
}

\author{
Azzah Nor Laila \\ UNISNU Jepara \\ email: azzah@unisnu.com
}

\begin{abstract}
This research aims to look for the humanist side of lafadz qital (command for war) in Islam. Using a qualitative descriptive method with the literature study approach, the writer found a number of qital commands in Islam. Based on the results of the analysis mentioned that the word qital is masdar from the word qatala which means battle or war. There are two terms that often lead to an inaccurate understanding between the words al-qital and al-qatl, both of them look the same, but both have different clear meanings and definitions. Al-qital means war or battle which is defined by the existence of two parties who both attack each other and seek murder to counter the efforts of the opposing party. Unlike the meaning of al-qatl which means murder which is defined as an attempt to kill another people. The command of qital in Islam can be analyzed as a command to fight in an effort to defend itself from enemy attacks or to contain and stop attacks from the enemy, not to say murder.
\end{abstract}

Keywords: qital, war, Islamic history, interpretation, the Qur'an

\begin{abstract}
Abstrak
Penelitian ini bertujuan untuk mencari sisi humanis pada lafadz qital (perintah untuk perang) dalam Islam. Menggunakan metode deskriptif kualitatif dengan pendekatan kajian pustaka penulis menemukan sejumlah perintah qital dalam Islam. Dan berdasarkan hasil analisis disebutkan bahwa kata qital merupakan masdar dari kata qatala yang memiliki arti pertempuran atau peperangan. Terdapat dua istilah yang sering menimbulkan pahaman yang kurang tepat yaitu antara kata al-qital dengan al-qatl keduanya terlihat sama namun keduanya memiliki arti dan definisi yang jelas
\end{abstract}


berbeda. Al-qital berarti peperangan atau pertempuran yang didefinisikan dengan adanya dua pihak yang keduanya saling menyerang serta mengupayakan pembunuhan untuk melawan upaya dari pihak lawan. Berbeda dengan makna al-qatl yang berarti pembunuhan yang didefinisikan sebagai upaya membunuh pihak lain. Perintah qital dalam Islam dapat dianalisa sebagai perintah berperang dalam upaya mempertahankan diri dari serangan musuh atau untuk menahan serta menghentikan serangan dari musuh, bukan berarti pembunuhan.

\section{Kata kunci:}

qital, peperangan, sejarah Islam, penafsiran, Alqur'an

\section{Pendahuluan}

Jihad merupakan salah satu ajaran Islam yang sering disalahpahami oleh para pengamat Barat. Istilah jihad digambarkan sebagai bentuk penyerangan tentara Muslim ke berbagai wilayah di Timur Tengah atau tempat lain serta memaksa masyarakat non-Muslim agar memeluk Islam dengan cara kekerasan. Citra tersebut diperburuk dengan munculnya beberapa peristiwa ekstrim seperti ledakan bom, aksi teror, maupun tindakan radikal yang dilakukan sebagian orang Islam. Kelompok itu disinyalir sebagai jaringan Islam radikal yang mengikuti paham radikalisme (Azra 1996). Hal itulah yang kemudian dijadikan celah atau pijakan sebagian pihak dalam mengkritik Islam sebagai agama yang membenarkan tindakan teror atau radikal.

Kelompok yang disinyalir radikal di Indonesia seperti Lembaga Dakwah Islam Indonesia (LDII), Jama'ah Ahmadiyah Qadian, Hizbut Tahrir Indonesia, Jama'ah Syi'ah yang dikenal dengan komunitas Ikatan Jama'ah Ahli Bait Indonesia (IJABI), Salafi Jihadi (JI), Jamaah Tauhid Wal Jihad (TWJ) dengan aktifitas rutinnya Forum kajian Islam Millah ibrahim (FKIMI), dan kelompok-kelompok lain. Beberapa aliran tersebut termasuk kelompok yang memiliki doktrin radikal, keras, dan fanatik buta pada doktrin masing-masing.

Berdasarkan perbedaan cara pandang, ada tiga kelompok dalam Islam yang berbeda pendapat tentang jihad. Pertama, kelompok yang mengusung untuk memusnahkan serta menghilangkan jihad. Seperti kelompok 
penganut paham sekularisme. Kedua, kelompok yang menyerukan perang dengan dalih jihad melawan kaum kafir atau semua non Muslim. Seperti kelompok penganut paham radikalisme. Ketiga, kelompok moderat yang bersikap pada poros tengah. Kelompok moderat lebih bersikap bijak, dalam memahami jihad mendasarkan kepada ilmu, hikmah, dan realitas sosial (alQaradhawi 2011). Dari klasifikasi kelompok tersebut menunjukkan adanya pemetaan kelompok secara umum dalam merespons isu jihad di kalangan umat Islam Indonesia.

Dalam memaknai jihad juga ada beragam pendapat. Menurut Chirzin jihad mengandung dua pengertian. Dalam arti sempit jihad adalah perang di jalan Allah. Dalam arti luas, jihad merupakan segala usaha yang memerlukan keridaan Allah baik yang berbentuk ibadah dalam artian khusus yaitu bersifat individual maupun ibadah umum yang bersifat kolektif (Chirzin 2006). Sedangkan menurut kelompok Islam radikal jihad adalah perjuangan membela Islam melawan non muslim. Perbuatan ekstrim yang mereka lakukanmerupakansuatu perjuangan atau jihad. Aksi teror, pembunuhan diri dengan bom, serta beberapa aksi melawankelompok yang berbeda dengan ajarannya dianggap bentukpenerapan doktrin jihad dalam sikap nyata (Kasjim 2009). Doktrin itu menguatkan anggapan sebagian penganut paham Islam radikal bahwa kematian dalam aksi radikal atau jihad dalam persepsi mereka tersebut termasuk syahid. Dimana mati syabid merupakan kondisi akhir manusia yang diidamkan umat Islam dalam akhir hidupnya di dunia.

Melekatnya citra jihad sebagai aksi radikal, perang, menyerbu dan memaksa orang dengan konfrontasi fisik atau kekerasan, pada akhirnya dapat mereduksi dan mengabaikan prinsip-prinsip perdamaian serta mempersempit pengertian jihad dalam Islam (Rohimin 2006). Oleh karena itu perlu adanya usaha membentengi masyarakat agar tidak mudah mengikuti paham atau ideologi aliran radikalisme. Praktek radikalisme agama belakangan ini mengalami eskalasi yang sangat signifikan, dan 
umumnya dikendarai oleh kelompok garis keras yang disebut ISIS yang berkeinginan mendirikan negara Islam dan konflik yang mereka buat dalam skala yang besar yaitu konflik di ranah Internasional (Chasbullah \& Wahyudi 2017).

Istilah radikalisme seringkali dikaitkan juga dengan fundamentalisme Islam atau dikenal dengan ekstrimisme dalam Islam, atau Islam radikal atau biasa disebut dengan integrisme, Islamisme dan revivalisme (Abdullah 2016).

Pemahaman secara tekstual literal pada teks-teks agama tanpa meninjau sisi historinya dapat melahirkan perilaku yang anarkis, tidak toleran serta cenderung destruktif, meski demikian model pemahaman seperti ini tidak dapat dielakkan lagi, seperti halnya pemaknaan qital secara pragmatis sering dipahami dengan "boly war". Sebagian sarjana Barat berkesimpulan bahwa Islam tersebar karena peperangan yang sering disebut dengan qital ayat-ayat tersebut dipersepsikan sebagai bukti bahwa Islam merupakan agama yang dekat dengan terorisme dan radikalisme (Chasbullah \& Wahyudi 2017). Yang terjadi saat ini pembacaan pada nash al-Quran maupun hadis hanya dilakukan secara substansial atau tekstualis dan tidak dikorelasikan sesuai konteksnya, hal ini mnegakibatkan kesalahpahaman pada pemahaman makna qital dalam Islam (Darajat 2016).

Kajian hadis yang membahas tentang jihad telah banyak dibahas oleh peneliti lain, namun kajian hadis ini lebih spesifik membahas tentang term jihad dalam hadis, diantara term jihad ialah lafadz qital, dari lafadz tersebut banyak melahirkan paham radikal dari Islam dan mengesankan bahwa Islam ialah agama yang mengajarkan peperangan. oleh karenanya sangat diperlukan kajian yang menguak nilai humanis dari lafadz qital. Sehingga membantah argumen yang mengatakan bahwa munculnya lafadz qital dalam Islam merupakan simbol radikalisme ajaran Islam.

Kajian penelitian ini fokus pada kajian hadis, maka sumber data primer yang dijadikan rujukan adalah Kutub al-Ahadis al-Tis'ah. Baik Kutub 
Sibah a al-Mustakhrajât (Sahih Bukhari, Sahih Muslim), Kutub Sunan dan Muwatta' (Jami' At-Tirmizi, Sunan Abi Daud, Sunan An-Nasa'i, Sunan Ibn Majah, Sunan Ad-Darimi, Muwatta' Malik, Sunan Kubra li an-Nasa'i, Sunan Dar al-Qutni) dan juga kitab Musnad Ahmad Ibn Hambal. Untuk memudahkan pencarian redaksi hadis dalam kitab-kitab tersebut penulis menggunakan aplikasi software Jawâmi' Al-Kalim, Software Mausu'âh AlHadis Al-Syarif maupun Maktabah Syamilah. Sedangkan data sekunder yang penulis gunakan adalah kitab syarah hadis, asbâb al-wurûd hadis, buku, jurnal, sumber internet serta data lain yang berkaitan dengan tema. Selain itu, buku-buku atau penelitian seputar jihad lainnya.

Berdasarkan fokus kajian tentang hadis Rasulullah, secara umum menggunakan metode penelitian hadis yaitu metode tematik dan takhrij hadis. Metode tematik adalah suatu usaha pengkajian hadis berdasarkan tema yang diteliti, dengan memerlukan pendekatan berbagai disiplin ilmu (Rusli 2010). Dengan langkah awal menghimpun hadis sesuai dengan tema yang sama yakni tentang jihad dan term yang semakna. Dalam proses mengumpulkan data hadis tentang tema tersebut, penulis menggunakan metode takhrij bil maudu' dan takhrij bi laf zi.

Metode takbrij bil maudu' adalah metode penelusuran hadis berdasarkan pada tema. Sedangkan takhrij bi lafzi adalah metode penelusuran hadis melalui kata kunci dari matan hadis baik dari permulaan, pertengahan atau akhiran (Khon 2010). Dalam hal ini untuk takbrij bil maudu', penulis menggunakan kunci tema jihâd. Namun karena banyaknya hadis, lalu penulis fokuskan dengan takhrij bi lafz̨i pada kata kunci jihâd, qitâl, nafr, harb, gazw. Selanjutnya menelusurinya dalam kitab kamus hadis seperti Mu'jam Al-Fahras Li Al-faz, al-Hadis atau menggunakan aplikasi seperti Jawâmi' Al-Kalim dan Mausu'ab al-Hadis al-Syarif.

Selanjutnya memahami hadis berdasarkan latar belakang kondisi dan tujuannya. Dalam tahap ini selain memahami asbâb al-wurûd hadis, penulis akan mencoba menelusuri data sejarah budaya masyarakat Arab 
pada zaman Rasulullah. Penelitian hadis tidak bisa lepas dari fakta sejarah dan budaya pada masa Rasulullah, karena hadis merupakan pernyataan, perilaku, keadaan dan taqrir Nabi. Sehingga dalam prakteknya penggalian sejarah menjadi penting, dan butuh bantuan data berdasarkan pada sejarah yang telah digali oleh para sejarawan (Kartodirdjo 1992).

Langkah selanjutnya proses kritik sanad. Langkah awalnya melakukan i'tibâr, yaitu proses menyertakan sanad-sanad lain dari suatu hadis tertentu, dimana hadis itu pada bagian sanadnya tampak hanya seorang perawi saja, dengan menyertakan sanad tersebut akan dapat diketahui apabila ada perawi lain atau tidak. Setelah menemukan beberapa sanad, kemudian meneliti kualitas sanad-sanad tersebut.

Meskipun secara rinci objek yang diteliti sangat beragam meliputi: kualitas pribadi dan kapasitas intelektual perawi, meneliti Al-Jarb wa at-Ta'dîl, persambungan sanad, meneliti syuzuz dan 'illat sampai menyimpulkan hasil penelitian (Ismail, 1992). Namun karena sudah banyaknya kitab hadis yang sudah ditakhrij dan ditahqiq para ahli hadis, maka dalam kritik sanad ini penulis akan merujuk pada beberapa kitab hadis yang sudah ditahqiq oleh para mubaqqiq hadis seperti Albani, as Suyuthi, maupun dalam kitab syarah hadis yang sudah dijelaskan tentang kualitas hadisnya diantaranya seperti kitab Fathul bâri, Bulîghul marâm dan kitab lainnya.

Sedang untuk proses selanjutnya adalah kritik matan hadis, adapun langkah-langkah penelitiannya sebagai berikut: 1). Membandingkan matan hadis yang diteliti dengan ayat-ayat al-Qur'an. 2). Membandingkan matan hadis dengan beberapa matan hadis lain yang semakna untuk mengetahui kemungkinan Idrâj, Ziyâdab atau Ta'arud. 3). Membandingkan matan hadis dengan realita serta data sejarah. 4). Memperhatikan lafal hadis beserta maknanya, apakah lafal tersebut beserta maknanya kemungkinan pantas atau memang benar-benar pernah diucapkan oleh seorang Nabi atau tidak. 5). Memperhatikan makna teks hadis, apakah bertentangan dengan ushul as-syari'ab dalam Islam atau tidak. 6). Meneliti matan hadis, apakah terdapat sesuatu yang janggal dan tidak dapat diterima akal sehat atau tidak. 
Dalam rangka menemukan makna dari istilah jihad dan beberapa term yang semakna dalam hadis, penulis menggunakan metode content analysis. Proses analisis makna dan kandungan teks-teks hadis secara deskriptif, kritis dan reflektif. Secara deskriptif berarti menguraikan, memaparkan atau menggambarkan data dengan kata-kata secara jelas dan terperinci. Selanjutnya data yang diperoleh diolah dengan kritis dan analisis yang tajam, kemudian hasilnya direfleksikan dengan konteks kekinian. Untuk mendapatkan hasil analisis penelitian secara komprehensif, maka diperlukan pendekatan metode lain. Dalam penelitian ini penulis menggunakan pendekatan metode hermeneutika untuk mengungkap makna dan spirit dari teks yang akan dikaji seputar jihad.

\section{Genealogi Perintah Perang dalam Islam}

Dalam sejarah kehidupan pra Islam, ada budaya masyarakat nomaden melakukan penyerbuan atau semacam razia terhadap orang lain untuk memenuhi kebutuhan hidup mereka. Aksi penyerbuan atau semacam razia tersebut dikenal dengan ghazw. Hal itu karena secara karakter penduduk gurun pasir termasuk keras dan memiliki budaya sosial arogan. Merampok, menyerbu dengan kilat meruapakan salah satu pekerjaan lakilaki masyarakat Badui (Hitti 30-31).

Perintah jihad telah ada sejak awal mula Islam, berupa perintah menyembunyikan imannya kepada Allah Swt. babak baru perjuangan Islam dimulai sejak turun perintah untuk menyiarkan Islam secara terbuka (QS. 87: 6 dan 94: 8) kemudian berlanjut pada perintah untuk berhijrah dalam perintah hijrah tersebut belum ada perintah perang fisik antara Muslim dan Musyrikin di Mekkah, meskipun penganiayaan sering dialami oleh kaum Muslimin (Agus 2013).

Peperangan yang pernah diikuti oleh Rasulullah Saw. tercatat kurang lebih 19 sampai 21 kali yang dikenal dengan ghazwah (perang yang dipimpin oleh Rasulullah Saw. langsung) yang melibatkan pasukan besar. 
Adapun perang yang tidak diikuti oleh Rasulullah Saw. atau Rasulullah Saw. mengutus pasukan dan tidak memimpinnnya secara langsung disebut sebagai sariyyah dan jumlah peperangan tersebut menurut sejarah berkisar antara 35 sampai 42 kali peperangan (Rohimin, 2016). Dilihat dalam konteks sejarah tersebut timbul persepsi dari dunia barat bahwa Islam sangat kental kaitannya dengan perang bahkan berasumsi bahwa Islam dikembangkan dengan peperangan.

Perang dalam agama Islam ialah bagian dari jihad yang bernilai tinggi dihadapan Allah Swt. ketika dilakukan untuk meninggikan kalimat Allah swt. dan untuk merealisasikan tujuan dari diturunkannya syariat Allah Swt. dengan tetap memelihara agama, jiwa, kehormatan, harta, akal dan keturunan. Perang dalam Islam diartikan sebagai upaya optimalisasi dalam mengerahkan seluruh potensi dalam rangka membela Islam, memajukan Islam. Jihad tidak dipakai sebagai tujuan namun sebagai sarana merealisasikan syariat Islam. Oleh karena jihad merupakan syariat maka memiliki aturan pula seperti ibadah-ibadah lain yang telah disyariatkan sebagaimana sholat, zakat, puasa serta haji.

Secara historis, istilah jihad yang diungkapkan dalam bentuk fi'il amar atau kata perintah awalnya muncul pada wahyu yang turun di Makkah dengan kronologi turun QS. Al-Furqon (25): 52, QS An-Nahl (16): 110 dan Al-Ankabut (29): 6 dan 69 (Agus 2013) Dimana saat itu Rasululah Saw.belum melakukan hijrah ke Madinah. Pada surat al-Furqan ayat 52, "Maka janganlah kamu mengikuti orang-orang kafir dan berjihadlah terbadap mereka dengan al-Qur'an dengan jihad yang besar."

Ayat tersebut diawali dengan larangan patuh pada kaum kafir kemudian perintah untuk berjihad terhadap mereka menggunakan alQur'an. Hal itu menunjukkan perintah jihad pada periode Makkah tersebut sudah ada, akan tetapi bukan ajakan untuk berperang secara fisik menggunakan senjata tajam. Pada ayat lain juga dijelaskan bahwa jihad pada masa awal dakwah Islam lebih bersifat ajakan untuk bersungguh- 
sungguh mencari Ridha Allah. Sebagaimana pada surat al-Ankabut ayat 69, "Dan orang-orang yang berjihad (untuk mencari keridhaan) kami, benar-benar akan kami tunjuk.kan kepada mereka jalan-jalan kami. Dan sesunggubnya Allah benar-benar beserta orang-orang yang berbuat baik."

Berdasarkan gambaran kandungan ayat tersebut, menujukkan bahwa saat itu umat Islam belum terlibat pada peperangan. Secara politik dan ekonomi Umat Islam masih lemah. Sehingga perintah jihad pada masa awal Islam tersebut lebih pada ajakan berusaha dengan sabar. Baik dalam konteks menghadapi kaum kafir maupun menjaga agama untuk meraih Ridlo Allah. Perintah berjihad pada periode Mekkah menggambarkan, agar umat Islam bersikap apa adanya dalam menerima amanat, bersikap peduli dan memberi maaf, memberi bantahan setelah dengan hikmah, berucap kata yang baik, menolak dengan sopan serta tidak bersikap sebagai penguasa (Muhtarom 2016)

Dalam beberapa literatur sejarah Islam menjelaskan bahwa agama Islam disebarkan melalui beberapa tahap. Tahap pertama, dakwah Islam secara sembunyi-sembunyi yang mana berlangsung dalam kurun waktu kurang lebih tiga tahun. Tahap kedua, tahap dakwah Islam secara terang-terangan yang menyeru hanya sebatas dengan lisan, dakwah ini berlangsung sampai Rasullullah hijrah ke Madinah. Tahap ketiga, dakwah Islam secara terang-terangan yang disertai memerangi orang yang sengaja memerangi umat Muslim terlebih dahulu, dakwah ini berlangsung sampai peristiwa Hudaibiyyah. Tahap keempat, tahapan dakwah secara terangterangan dengan memerangi orang-orang yang berusaha menghentikan dakwah Islam. Jika melihat sejarah perkembangan dakwah Islam ketika umat Muslim telah diperintahkan untuk dakwah secara terang-terangan kaum Muslim tidak dapat lepas dari segala bentuk tekanan maupun intimidasi dari kafir Quraisy (al-Buti 2008).

Tekanan dan intimidasi tersebut berbentuk tekanan mental, penyebaran isu bahwa Nabi Muhammad ialah seorang pendusta, ahli sihir 
dan orang gila, sampai merambah pada tekanan fisik yang dialami oleh Nabi dan umat Islam, Rasulullah Saw dilempari isi perut domba pada saat beliau melakukan salat, Uqbah bin Abi Mu'ti juga meletakkan kotoran unta dipundak Rasulullah saat beliau sujud di depan Ka'bah, Uqbah juga meludahi Rasulullah Saw. Umpatan dan celaan juga sering Rasullah Saw dapatkan dari orang-orang kafir (al-Mubarakfuri 2008). Tekanan dan intimidasi bukan hanya dirasakan oleh Rasulullah Saw tapi juga dirasakan oleh kaum Muslim, seperti halnya yang dirasakan oleh Bilal yang disiksa oleh Umayyah bin Khalaf, Bilal diikat dan diletakkan batu besar di atas tubuhnya ditengah teriknya panas matahari. Amar bin Yasir beserta kedua orang tuanya disiksa oleh Bani Makhzum sampai Ummu Yasir meninggal demi mempertahankan keimanannya, beliau tercatat sebagai Muslimah pertama yang syahid di jalan Allah dan Rasulullah berkata "sesunggubnya surga telah dijanjikan untuk kalian" (al-Mubarakfuri 2006).

Dapat penulis simpulkan bahwa perintah untuk berperang bagi Muslim turun dalam dakwah Islam tahap ketiga yakni setelah hijrah yang dilakukan oleh Nabi Muhammad Saw beserta para sahabat ke Madinah. Hal ini sesuai sejarah bahwa perang Badar ialah perang yang pertama kali dilakukan oleh umat Islam untuk melawan musuh dan terjadi setelah hijrah. Dan perang tersebut atas seizin Allah sesuai dalam firmannya surat al-Hajj ayat 39-40.

"Telab diizinkan (berperang) bagi orang-orang yang diperangi, karena sesungguhnya mereka telah dianiaya.Dan sesunggubnya Allah, benar-benar Maha Kuasa menolong mereka itu. (39) (yaitu) orang-orang yang telah diusir dari kampung halaman mereka tanpa alasan yang benar, kecuali karena mereka berkata: "Tuhan kami hanyalah Allab". Dan sekiranya Allab tiada menolak (keganasan) sebagian manusia dengan sebagian yang lain, tentulab telah dirobobkean biara-biara Nasrani, gereja-gereja, rumah-rumah ibadat orang Yabudi dan masjid-masjid, yang di dalamnya banyak disebut nama Allah. Sesunggubnya Allah pasti menolong orang yang menolong (agama)Nya.Sesunggubnya Allab benar-benar Maba Kuat lagi Maba Perkasa. 
Dalam menafsirkan ayat tersebut 'Abdullāh Ibn 'Abbās (w. 68 H) menyatakan bahwa "mereka (orang-orang yang dizalimi dan diberikan izin untuk berperang) adalah Muhammad Saw dan beserta para sahabatnya, yang telah berhijrah dari Makah menuju ke Madinah (al-Tabari 2008). Hal yang sama pun diungkapkan oleh Mujāhid (w. 104 H) menurutnya "yang dimaksudkan dengan mereka yang diizinkan berperang karena telah dizalimi ialah kaum mukmin yang berhijrah dari Makah menuju ke Madinah. Yang pada awalnya mereka dilarang untuk berperang, namun kemudian Allah Swt. mengizinkannya yaitu untuk memerangi orang-orang kafir" (al-Tabari, 2008). Dapat diambil kesimpulan awal bahwasanya hadis perang baru muncul setelah adanya perintah perang dari al-Quran. Hal serupa juga yang dinyatakan oleh Ibn Rajab al-Hanbali (w $795 \mathrm{H}$ ) pada saat mensyarah hadis-hadis tentang perang, bahwa "semua hadis yang berhubungan dengan perang baru muncul setelah hijrah" (al-Hanbali, 2010). Sebelumnya, umat Muslim diminta untuk senantiasa bersabar dalam menghadapi berbagai bentuk kezaliman yang telah dilakukan oleh orang-orang kafir.

Perang yang dilakukan umat Islam merupakan pilihan terakhir, di mana objek perang kaum kafir atau non Muslim itu dibagi menjadi dua. Pertama, kelompok non muslim yang menegaskan untuk berdamai dengan kaum muslimin. Kedua, kelompok yang menyatakan untuk memusuhi muslim yang disebut dengan mubaribun (Arifin, 2011). Dalam pandangan Syikh Abdul Aziz periode jihad dalam arti perang, atau dalam istilah lain qital dibagi menjadi tiga periode. Pertama, periode belum diwajibkannya peperangan, tetapi umat Islam diizinkan perang. Hal ini dilandasi ayat dari surat al-Hajj ayat 39, "Telah diizinkan (berperang) bagi orang-orang yang diperanggi karena sesunggubnya mereka telah dianiaya. Dan sesunggubnya Allab benar-benar Maha Kuasa menolong mereka."

Kedua, periode umat Islam hanya dianjurkan untuk berperang dengan orang yang memusuhi dan melawan dengan peperangan saja. 
Sedangkan kelompok kafir yang tidak melawan dengan peperangan tidak boleh diperangi. Hal itu didasarkan pada dalil surat al-Baqarah ayat 190, 'Dan perangilah di jalan Allah orang-orangyang memerangi kamu, (tetapi) janganlah kamu melampaui batas.Karena sesunggubnya Allab tidak menyukai orang-orang yang melampaui batas.” Ketiga, periode dimana adanya perintah secara jelas untuk memerangi kaum musyrik. Hal itu berdasarkan firman Allah pada surat al-Anfal ayat 39, "Dan perangilah mereka, supaya jangan ada fitnah dan supaya agama itu semata-mata untuk. Allah. Jika mereka berhenti (dari kekeafiran), maka sesungguhnya Allah Maha Melihat apa yang mereka kerjakan."

Pada masa Nabi hampir seluruh wilayah Hijaz, Yaman dan sekitarnya menjadi daerah kekuasaan Islam. Nabi sebagai Rasul merupakan pemimpin mereka, mendapat bagian seperlima dari rampasan perang, upeti, dan sedekah yang dahulu menjadi bagain para raja. Namun beliau tidak mengambil keuntungan untuk pribadi atau disalahgunakan, melainkan semua itu beliau sampaikan kepada yang berhak. Beliau juga membangun, menyatukan umat Islam dan membantu mereka baik dengan kekuatan moril maupun materil (An-Nabhani, 2006).

\section{Berperang di Jalan Allah}

Konstruksi teoritis yang memberi label bahwa perang merupakan sebuah kewajiban adalah hal yang tidak sepenuhnya benar. Dalam Islam konflik, perang dengan segala bentuk kekerasan yang lain sangatlah dibenci oleh manusia dan agama Islam, namun boleh jadi sesuatu yang dibenci tersebut justru dapat membawa pada kebaikan manusia (Fatwa 2012). Hakikat tujuan dari perang dalam Islam adalah menghilangkan kekafiran, kemusyrikan, kezaliman, menyebarkan dakwah Islam, dan meninggikan kalimat Allah. Apabila tujuan utama jihad tersebut sudah terealisasi tanpa harus ada jihad fisik atau peperangan, umat Islam tidak harus berperang (atTuwaijry 2007). Intinya perang fi sabilillah bertujuan untuk mendapat ridlo Allah swt dengan perang atau secara fisik merupakan pilihan terakhir dan tidak dilakukan begitu saja tanpa aturan.

DINIKA, Volume 4, Number 3, September - December 2019 
Jihad juga memiliki beberapa keutamaan, di antaranya memperoleh derajat yang tinggi, berdasarkan firman Allah swt pada surat at-Taubah ayat 20, "Orang-orang yang beriman dan berbijrah serta berjihad di jalan Allah dengan harta, benda, dan diri mereka, adalah lebih tinggi derajatnya di sisi Allah, dan itulab orang-orang yang mendapat kemenangan." Orang yang berjihad di jalan Allah juga termasuk golongan manusia yang paling utama. Hal itu berdasarkan hadis Rasulullah

"Telab mengabarkan kepada kami Abu Bakar dari Ahmad bin Hasan alQadhi, telah mengabarkan kepada kami Abu Sahal bin Ziyad al-Qaththan, telah menceritakan kepada kami Abu al-Yaman, telah mengabarkan kepadaku Syu'aib dari az-Zuhri, telah menceritakan kepadaku 'Atha' bin Yazid, sesunggubnya telah menceritakan kepadanya Abu Säid al-Kbudbry RA.,sesunggubnya telah dikatakan: "Wabai Rasulullah saw siapa manusia yang paling utama?", maka Rasulullah saw menjawab: "Seorang mukmin yang berjihad di jalan Allah dengan jiwanya dan hartanya". Maka ia bertanya: "Kemudian siapa?", Rasulullah saw menjawab: "Seorang mukmin dalam suatu bangsa dari beberapa bangsa yang bertakwa pada Allah swt dan menyeru manusia agar terbindar dari keburukannya" (H.R. Bukbari).

\section{Qital dalam Hadis}

\section{Perintah Memerangi Kaum Penentang Islam}

Dalam hadis yang diriwayatkan oleh Abdullah bin Umar, Rasullah Saw. telah diperintahkan oleh Allah Swt. untuk memerangi manusia hingga mereka bersyahadat bahwa tiada Tuhan yang patut disembah melainkan Allah Swt. dan Nabi Muhammad adalah Rasulullah. Hadis ini berstatus sahih yang diriwayatkan oleh al-Bukhari dan Muslim. Berikut hadis yang diriwayatkan oleh Abdullah bin Umar:

"Telah menceritakan kepada kami Abdullab bin Mubammad al-Musnady, ia berkata: telah menceritakan kepada kami Abu Raubin al-Haramy bin Umarah berkata, Dari Abdullah bin Umar berkata, Rasulullah Saw. bersabda "aku diperintabkan untuk memerangi manusia bingga sampai mereka bersaksi babwa tidak. ada Tuban selan Allah Swt. dan sesunggubnya Nabi Mubammad adalah utusan Allah Swt. dan sampai mereka mendirikan 
shalat dan membayar zakat. Jika mereka melakukan itu semua maka mereka telah menjaga darah serta harta mereka dariku kecuali dengan haknya, serta perbitungan mereka berada di tangan Allah Swt.”

Hadis tersebut berisi perintah untuk memerangi orang-orang kafir sampai mereka masuk Islam bukanlah bentuk kekerasan dan paksaan agar memeluk agama Islam. Akan tetapi hadis tersebut lahir menunjukkan bentuk perlawanan umat Islam dan juga bentuk usaha pembebasan diri umat Islam dari keterkekangan beragama yang dilakukan oleh kaum kafir, sehingga penduduk Arab memiliki kebebasan beragama Islam tanpa adanya intimidasi, ancaman dan siksaan dari pihak kaum kafir.

Menurut pandangan Yusuf al-Qardhawi, "walaupun Hadis ini (Sesungguhnya Allah mengutusku dengan pedang menjelang Hari Akhir) dari segi sanad merupakan hadis sahih, namun dari segi matan hadis Nampak tidak sejalan dengan ajaran Al-Qur'an yangmana tidak pernah mengatakan bahwa Nabi Muhammad Saw. diutus dengan pedang, namun beliau diutus untuk memberikan petunjuk pada umat manusia dengan agama kebenaran, yang penuh cinta dan kasih sayang, serta memberi obat dan nasehat kepada seluruh manusia (al-Qardhawi 2011). Begitu pula Hadis tentang, Aku diutus untuk memerangi manusia sampai mereka bersaksi tidak ada tuhan selain Allah, 'menurut Ibnu Hajar seperti yang dikutip oleh Al-Qaradhawi bahwa mayoritas ulama cenderung menafsirkan kata anNaas dalam hadis ini adalah kaum musyrik Arab yang menantang dakwah Islam sejak kedatangannya (Ibn Mubarak,1997).

\section{Pemberontakan}

Dalam hadis riwayat Sulaiman bin Harb diceritakan bahwa qitaldalam teks hadis tersebut menunjukkan suatu pemberontakan. Sebagaimana dua hadis berikut.

"Pada hari kiamat, akan dipasang bendera untuk setiap orang yang melanggar perjanjian." Sesunggubnya kita telah membaiat orang ini (yaitu 
Yazid, pen.) di atas baiat Allah dan Rasul-Nya. Dan aku tidak mengetahui pelanggaran yang lebih serius daripada ketika seseorang telah membaiat seseorang di atas baiat Allah dan Rasul-Nya, kemudian dia memasang peperangan (pemberontakan) kepadanya. Dan sungguh aku tidak melihat salah seorang di atas kalian yang telah mencopotnya (dari jabatan sebagai khalifah) dan ikut-ikutan di dalamnya, kecuali ada pemisah di antara aku dan kalian"(Mubarak 1997).

"Telah diceritakan kepada kami Muhammad bin 'Ar'arah, ia berkata: telah menceritakan kepada kami Syu'bah, dari Zubaid, ia berkata: Saya bertanya pada Bapak. Wa'il dari al-Murjiah, lalu ia berkata: telah menceritakan kepadaku Abdullab bahwa sesunggubnya Nabi saw bersabda: penutup atau penghalang seorang muslim adalab kefasikan, dan peperangannya atau pemberontakannya adalah kufur".

\section{Humanisme Perang}

Qital merupakan masdar dari kata qatala yang memiliki arti pertempuran atau peperangan (Ibnu Faris, 1994). Qital juga musytaq dengan lafal qatala yang mengikuti wazan facala dan juga dianggap bentuk mashdarnya. Dalam kaidah bahasa Arab, wazan faa'ala mengandung makna musyarokah ( bermakna saling). Dimana pelaku pada saat yang samajuga menjadi obyek atau penderita (al-Ghalayani 1993). Hal itu menunjukkan bahwa qital bermakna perang dengan tekanan makna upaya untuk membunuh musuh dari kedua belah pihak. Pelaku atau pembunuh berusaha membunuh lawan, dan sebaliknya pada saat yang sama lawan juga berusaha membunuhnya.

Berdasarkan kajian dari aspek bahasa tersebut, dapat dipahami bahwa ada dua istilah yang musytaq dari huruf qaf, ta', dan lam yang diartikan perang atau membunuh yaitu kata al-qital dan al-qatl. Kedua lafal tersebut terlihat sama namun keduanya memiliki arti berbeda. Alqital berarti peperangan atau pertempuran yang didefinisikan dengan adanya dua pihak yang keduanya saling menyerang serta mengupayakan pembunuhan untuk melawan upaya dari pihak lawan. Sedangkan al-qatl 
bermakna pembunuhan sebagai upaya melawan pihak lain. Perintah qital dalam Islam dapat dianalisa sebagai perintah berperang dalam upaya mempertahankan diri dari serangan musuh, menahan, serta menghentikan serangan dari musuh, bukan berarti pembunuhan.

Perang atau qital dalam Islam bukanlah satu satunya konsep utama yang dikembangkan dalam agama Islam. Dalam syariat Islam perintah perang dilakukan dalam rangka mempertahankan diri dari serangan musuh. Setiap hukum dalam Islam selalu diikuti dengan berbagai aturan teknis atau operasionalnya, begitupula perang atau qital dalam Islam, terdapat aturan yang menyertainya (Junaidi 2016). Qital baru terjadi setelah kaum Muslim mempunyai sebuah kekuatan (Negara) yang lengkap dengan segala perangkatnya. Karena keberadaan sebuah Negara adalah salah satu unsur jihad, yang dengan peperangan mampu manklukkan Negara lain, dan negaralah yang mempunyai wewenang dalam memerintahkah serta mengontrol jalannya peperangan dengan ketentuan-ketentuan yang telah berlaku dalam Islam (Asmara 2016).

Hadis yang diriwayatkan oleh Ibnu Umar di atas berisi perintah untuk memerangi orang-orang kafir sampai mereka masuk Islam hal ini bukan berarti Islam mnegajarkan kekerasan dan paksaan kepada orang lain agar memeluk agama Islam. Namun melihat sejarah keluarnya hadis tersebut lahir karena umat Islam terkekang, terintimidasi, terancam kebebasannya oleh orang kafir dalam beragama. Oleh karenanya perintah perang tersebut ditujukan agar penduduk Arab memperoleh kebebasan dalam memeluk Agama Islam. Perang adalah jalan alternative terakhir yang harus diupayakan untuk mewujudkan kedamaian umat, ketika perdamaian dalam kehidupan telah diganggu dan tidak dihargai lagi maka umat Muslim diizinkan oleh Allah Swt. untuk melakukan peprangan (Rosdin 2016).

Bahkan dalam menghadapi lawannya Rasulullah Saw. selalu berusaha mengupayakan jalan damai, perundingan serta pengiriman 
delegasi terlebih dahulu, setelah seluruh upaya damai tidak mampu ditempuh baru dengan cara peperangan (Saufan 2015). Perang dalam Islam bukanlah menjadi faktor dan tujuan, terdapat aturan syariat perang dalam Islam, oleh karenanya jika tujuan dari perang telah keluar dalam koridor aturan berarti perang tersebut tidak bernilai jihad, namun perbuatan keji yang ditolak dalam Islam. Berikut beberapa aturan perang dalam Islam. Umat Islam diperintahkan untuk memerangi musuh bila umat Islam diperangi. Hal ini sesuai dengan firman Allah Swt. dalam surat al-Baqarah ayat 190, "Dan perangilah di jalan Allab orang-orang yang memerangi kamu, (tetapi) janganlah kamu melampaui batas, karena sesunggubnya Allab tidak menyukai orang-orang yang melampaui batas."

Aturan selanjutnya terkait dengan membela orang Muslim atau orang lemah yang ditindas atau dianiaya oleh orang kafir, sesuai dengan firman Allah Swt. surat an-Nisa' ayat 75, “Mengapa kamu tidak mau berperang di jalan Allah dan (membela) orang-orang yang lemah baik laki-laki, wanita-wanita maupun anak-anak yang semuanya berdoa: "Ya Tuban kami, keluarkanlah kami dari negeri ini (Mekah) yang zalim penduduknya dan berilab kami pelindung dari sisi Engkau, dan berilah kami penolong dari sisi Engkau!. Perang dalam Islam tidaklah diperkenankan untuk membunuh wanita dan anak-anak yang lemah, hal ini sesuai dengan hadis Rasulullah Saw. berikut ini, "Telah menceritakan kepada kami Abmad bin Yunus, mengebarkan kepada kami al-Layst dari Nafi' sesunggubnya Abdullah Radbiyallabu anbu telab mengabarkan kepada kami: Babwa seorang wanita ditemukan di beberapa peperangan Nabi SAW terbunub. Maka Rasulullab SAW mengingkari pembunuban wanita dan anak-anak (al-Bukhari 1992).

Adapun maksud dari hadis tersebut ialah larangan untuk membunuh wanita maupun anak-anak yang tidak ikut berperang, karena apabila seorang wanita ikut berperang wanita tersebut boleh di bunuh karena statusnya seorang prajurit. Hal ini sesuai dengan firman Allah, "Kecuali orang-orang yang meminta perlindungan kepada sesuatu kaum, yang antara kamu 
dan kaum itu telah ada perjanjian (damai) atau orang-orang yang datang kepada kamu sedang hati mereka merasa keberatan untuk memerangi kamu dan memerangi kaumnya."

Aturan lain terkait dengan membuat dan menepati janji sesuai kesepakatan bersama, sebagaimana firman Allah Swt. dalam surat atTaubah ayat 8, "Bagaimana bisa (ada perjanjian dari sisi Allah dan Rasul-Nya dengan orang-orang musyrikin), padabal jikea mereka memperoleb kemenangan terbadap kamu, mereka tidak memelihara bubungan kekerabatan terhadap kamu dan tidak (pula mengindabkan) perjanjian. Mereka menyenangkan hatimu dengan mulutnya, sedang hatinya menolak. Dan kebanyakan mereka adalab orang-orang yang fasik (tidak menepati perjanjian). "Penyerangan secara mendadak tidak dibenarkan dalam Islam, bila sebelumnya terdapat perjanjian perdamaian dengan kelompok musuh. Namun penyerangan boleh dilakukan bila kelompok yang telah sepakat mengadakan perjanjian perdamaian tersebut telah melanggar perjanjian yang telah disepakati bersama.

Perang dalam Islam dilarang untuk memutilasi musuh, hal ini sesuai dengan hadis Rasulullah sebagai berikut, "Telah bercerita kepada kami Mubammad Saw. Bin al-Matsunna, bercerita kepada kami Muadz bin Hisyam bercerita kepadaku Abi Qatadah dari Hasan dari Hayyaj bin Imron, sesunggubnya Rasullah. Memotivasi kami untuk bertindak benar dan melarang kamu memutilasi (Abu Dawud, 1998). Dalam perang, Allah memerintahkan agar memaafkan musuh ketika mereka telah menyerah, hal ini sesuai dengan firman Allah dalam surat al-Baqarah ayat 192, "Kemudian jika mereka berhenti (dari memusubi kamu), maka sesunggubnya Allab Maha Pengampun lagi Maba Penyayang."

Perintah perang dalam Islam bertujuan menegakkan agama Islam dengan tetap memberlakukan syariah Islam, bukan bertujuan untuk membunuh orang non-Muslim dan membuat kerusakan di muka bumi. Bila tujuan perang dalam Islam hanya untuk memerangi non Muslim tentu dalam Islam tidak ada aturan yang mengatur tentang jizyah atau pajak keamanan atas non-Muslim. Peperangan dalam Islam sangat menghargai 
nilai-nilai kemanusiaan sebagaimana yang diajarkan oleh Islam (Suhaimi 2017). Dari pembahasan tersebut memperlihatkan bahwa Islam sangat menjunjung tinggi hak asasi manusia, menghormati perbedaan, Islam bukanlah agama yang anarkis, bukan agama yang menebarkan ketakutan dan teror, namun Islam ialah agama yang rahmatan lil alamin, menghormati dan menghargai setiap nyawa manusia.

\section{Simpulan}

Setelah melakukan penjabaran sederhana di atas, maka penulis dapat menarik kesimpulan bahwasanya perang merupakan bagian dari tahapan dakwah Rasulullah Saw. namun Islam agama yang sangat menjunjung tinggi nilai-nilai kemanusiaan, berjihad merupakan salah satu hal yang diperintahkan agama, dan qital/perang merupakan bagian dari jihad tersebut. Namun perang dalam Islam tetap menjunjung tinggi nilainilai kemanusiaan dan hak asasi manusia, hal ini terlihat dari hadis hadis Rasulullah saw. tentang perintah perang. Tentu hal ini tidak sesuai dengan tudingan non Muslim yang mengatakan bahwa Islam adalah agama yang identik kekerasan dan aksi terorisme. Bahkan dalam sejarah disebutkan bahwa perintah perang dalam Islam turun ketika umat Islam sudah mulai terdesak dan terancam kehidupannya oleh orang kafir. Kesalahpahaman tentang lafadz qital dipengaruhi oleh pemahaman secara tekstualis pada nash al-Quran maupun Hadis, serta pada pembacaan yang salah pada sejarah praktik qital pada periode awal Islam. oleh karenanya pembacaan komprehensif pada teks qital di al-Quran maupun Hadis harus disertai pembacaan secara cermat dan objektif pada bagaimana praktik perang tersebut dipraktikkan oleh Rasulullah Saw., generasi sahabat, tabiin dan generasi setelahnya sampai pada generasi saat ini, sehingga mendapatkan pemahaman yang tepat pada teks al-Quran maupun hadis. 


\section{Referensi}

Abdullah, Anzar. 2016. "Gerakan Radikalisme dalam Islam: Perspektif Historis," Addin 10, No.1.

Al Bukhari, Abdullah Muhammad bin Ismail. 1992. Shahih al Bukbari Juz. $V$. Beirut: Dar al Kitab al. 'Ilmiyyah.

Al-Hanbali, Ibn Rajab. 2010. Jami' al-Ulum wa al-Hikam Syarh Khamsin. Kairo: Dar al-Fajr li al-Turats.

Al-Rahman, Safi. 2008. Al-Rabiq al-Makbtum. Makkah: Rabithah al-Alam al-Islam.

Al-Tabari. 2008. Jami’ al-Bayan an Ta'wil al-Quran. Kairo: Dar Hijr.

Arifin, Johar, 2011, "Hadis-Hadis Nabi dalam Berinteraksi dengan Non Muslim "Muharibun”, Jurnal Ushuluddin, Vol. XVII, No.1, 54-65.

Asmara, Musda. 2016. "Reinterpretasi Makna Jihad dan Teroris," AlIstinbath: Jurnal Hukum Islam. Vol. 1, No. 1.

At-Tuwaijry, Muhammad bin Ibrahim bin Abdullah. 2007. Jihad fi Sabilillah, terj. Al-Fariq. Riyad: Islam House.

Azra, Azyumardi. 1996. Pergolakan Politik Islam dari Fundamentalisme, Modernisme Hingga Post-Modernisme. Jakarta: Paramadina.

Chasbullah, Arif. 2017. "Deradikalisasi terhadap Penafsiran Ayat-Ayat Qital," Jurnal Fikri, Vol. 2, No. 2 Desember.

Chirzin, Muhammad. 2006. Kontroversi Jihad di Indonesia: Modernis vs Fundamentalis Yogyakarta: Nuansa Aksara.

Darajat, Zakiya. 2016. "Jihad Dinamis: Menelusuri Konsep dan Praktik Jihad dalam Sejarah Islam," Ijtihad Jurnal Wacana Hukum Islam dan Kemanusiaan. Vol. 16, No. 1.

Faris, Ibnu. 1994. Mu'jam al-Maqâyî́s fì al-Lugah. Beirut: Dar al-Fikr.

Fatwa, Ach Fajruddin. 2012. "Islam dan Doktrin Militerisme," Al-Abkam Jurnal Pemikiran Hukum Islam. Vol. 22. No. 1. April. 
Junaidi, M. 2016. "Perang dan Jihad dala Perspektif Fiqh Siyasah Dauliyah (Telaah Historis Berbasis Teks Suci)," Jurnal Law and Justice, Vol.1 No.1 Oktober.

Kasjim. Salenda. 2009. Terorisme dan Jihad dalam perspektif Hukum Islam. Jakarta: Balitbang Diklat Depag RI.

Muhtarom, Ahmad. 2016. "Reorientasi Makna Jihad: Sebuah Tinjaun Historis Terhadap Makna Jihad Dalam Sejarah Umat Islam," Yaqzhan Vol. 2, No. 2, Desember.

Qardhawi,Yusuf. 2011. Ringkasan Fikih Jihad,. Jakarta: Pustaka AlKautsar.

Rohimin. 2006. Jihad Makna dan Hikmah. Jakarta: Erlangga.

Salim, Agus. 2013. "Jihad dalam Perspektif Hukum Islam," Jurnal Ushuluddin, Vol. XX. No. 02, Juli.

Saufan, Akhmad. 2015. "Strategi dan Diplomasi Perang Rasulullah,” Jurnal Lektur Keagamaan, Vol. 13. No. 1, 2015.

Suhaimi. 2017. "Reinterpretasi dan Reformulasi Makna Jihad dan Qital," El-Furqania Vol 4. No. 1, Februari.

Rosdin, Dede. 2016. "Islam dan Radikalisme: Telaah atas Ayat-Ayat Kekerasan dalam al-Quran," Addin, Vol. 10, No. 1. Februari. 
DINIKA, Volume 4, Number 3, September - December 2019 